\title{
Impact of Watering Frequencies and Rehydration on Physiological Responses of Indigenous Sheep
}

\author{
M. Sahana", R. J. Modi, M. M. Trivedi, M. M. Islam and K. N. Wadhwani \\ Department of Livestock Production Management, College of Veterinary Science and Animal \\ Husbandry Anand Agricultural University, Anand - 388 001, Gujarat, India \\ *Corresponding author
}

\section{A B S T R A C T}

\begin{tabular}{|l|}
\hline Ke y w o r d s \\
Watering \\
frequencies, \\
$\begin{array}{l}\text { Rehydration, } \\
\text { Physiological } \\
\text { responses, Sheep }\end{array}$ \\
\hline Article Info \\
\hline $\begin{array}{l}\text { Accepted: } \\
\text { 10 July 2020 } \\
\text { Available Online: } \\
\text { 10 August } 2020\end{array}$ \\
\hline
\end{tabular}

\section{Introduction}

Drinking water is an important requirement for livestock. Lack of sufficient water source can be a critically limiting factor in animal physiology and productivity (Alamer, 2010). Water ingestion by animal is influenced by different variables such as body weight, dry matter intake, energy intake, seasons (temperature, radiation and humidity), restriction effect, water quality, species, breed and physiological stages (Anonymous, 2007).

Changes in pulse rate, respiration rate and rectal temperature indicated the adaptability
Present experiment was conducted with the objective to studyimpact of watering frequencies and rehydration on physiological responses of indigenous sheep under intensive production system during hot humid season. Eighteen adult dry non pregnant farm born Patanwadi and Marwari female (25-35 kg) sheep were selected and divided randomly on the basis of body weight into three treatment groups viz., $\mathrm{T}_{1}$ : Control (watering thrice in a day), $\mathrm{T}_{2}$ : (watering twice in a day), $\mathrm{T}_{3}$ : (watering once in a day). The duration of experiment was 44 days (42 days of different watering frequencies and 2 days of rehydration phase). The experimental animals were maintained on conventional feed as per the recommendations of ICAR feeding standard (2013). All physiological responses (respiration rate and pulse rate at 7.30 a.m. and 2.30 p.m. and rectal temperature at 7.30 a.m.) except rectal temperature at 2.30 p.m. were at par among different watering frequencies. The present experiment indicated that the physiological parameters of experimental animals were non-significantly influenced by rehydration.

of animals to increased thirst periods. Dehydration due to thirst period provoked physiological mechanisms in the body in a manner that helped the animals to survive (Saini et al., 2013).There was a rise in body temperature of water deprived small ruminants as a result of their reduced thermoregulatory evaporation (Alamer, 2009). Water restriction regimen resulted in a significant $(\mathrm{P}<0.05)$ decrease of respiratory rate in intensively reared Lacaune ewes (Casamassima et al., 2016). The study was therefore conducted to investigate the impact of watering frequencies and rehydration on physiological responses of indigenous 
sheepunder intensive production system during hot humid season.

\section{Materials and Methods}

The present experiment was conducted at Livestock Farm Complex, College of Veterinary Science and Animal Husbandry, Anand Agricultural University, Anand. Eighteen adult farm born dry non pregnant female Patanwadi and Marwari sheep (25-35 $\mathrm{kg}$ ) were selected as experimental animals and divided in to three treatment groups on the basis of body weight comprising six animals in each treatment viz., $\mathrm{T}_{1}$ : Control (watering thrice a day), $\mathrm{T}_{2}$ : (watering twice a day), $T_{3}$ : (watering once a day). The duration of experiment was 44 days (42 days of different watering frequencies and 2 days of rehydration phase) under intensive production system in hot humid season $\left(1^{\text {st }}\right.$ September to $15^{\text {th }}$ October). Animals of $\mathrm{T}_{1}$ group was offered water at 8.30 a.m., 2.30 p.m., and 8.30 p.m. whereas group $\mathrm{T}_{2}$ at 8.30 a.m. and 8.30 p.m. and group $\mathrm{T}_{3}$ at 8.30 a.m. only.

The experimental animals were maintained on conventional feed as per the recommendations of ICAR feeding standard (2013). The physiological responses viz., rectal temperature $\left({ }^{\circ} \mathrm{F}\right)$, pulse rate (no./min.) and respiration rate (no./min.) of all the experimental animals were recorded by using doctor's thermometer, femoral artery and flank movements respectively, once in a week during different watering frequencies and daily in rehydration phase at 7.30 a.m. and 2.30 p.m. Meteorological parameters especially microclimatic parameters like dry and wet bulb temperature were recorded daily in the morning (7.30 a.m.) and afternoon (2.30 p.m.) during whole period of experimentation using sling psychrometer. The Temperature Humidity Index (THI) was calculated by using the formula; $\mathrm{THI}=0.72$ $(\mathrm{Cdb}+\mathrm{Cwb})+40.6$, Where, Cdb: dry bulb temperature $\left({ }^{\circ} \mathrm{C}\right)$ and $\mathrm{Cwb}$ : wet bulb temperature $\left({ }^{\circ} \mathrm{C}\right)$.

\section{Statistical Analysis}

The experimental data were analysed using completely randomized design (Snedecor and Cochran, 1991).

\section{Results and Discussion}

The temperature humidity index (THI) values recorded during the experiment are presented in Table 1. The THI values recorded at 2.30 p.m. were greater than the values recorded at 7.30 a.m. which indicated that afternoon was more stressful to the experimental animals.

Results of physiological responses of sheep under different watering frequencies and rehydration are presented in Table 2 to 4 . The pulse rate and respiration rate recorded at 7.30 a.m. and 2.30 p.m. were non-significantly influenced by watering frequencies. However, pulse rate recorded in animals of $\mathrm{T}_{3}$ group was higher followed by animals of $T_{2}$ and $T_{1}$ group.

The respiration rate of the experimental animals recorded at 7.30 a.m. and 2.30 p.m. increased in $\mathrm{T}_{2}(1.28$ and $3.07 \%)$ and $\mathrm{T}_{3}(1.6$ and $3.77 \%$ ) groups, as compared to control group. Experimental animals exhibited higher pulse rate and respiration rate at 2.30 p.m. as compared to 7.30 a.m., which might be due to increase in ambient temperature at 2.30p.m.

The rectal temperature recorded at 7.30 a.m. influenced non-significantly by watering frequencies. However, the rectal temperature recorded at 7.30 a.m. was highest in $\mathrm{T}_{3}$ followed by $\mathrm{T}_{2}$ and $\mathrm{T}_{1}$ groups. Rectal temperature of experimental animals recorded at 2.30 p.m. was influenced significantly $(\mathrm{P}<0.05)$ by watering frequencies. Sheep maintained on once a day watering showed 
significantly $\quad(\mathrm{P}<0.05) \quad$ higher $\quad$ rectal temperature at 2.30 p.m. as compared to twice and thrice a day watering, whereas twice and thrice a day watering groups remained at par. The results obtained reflected that there was an increasing trend in rectal temperature with increase in water restriction. The physiological parameters of experimental animals recorded at 7.30 a.m. and 2.30 p.m. influenced non-significantly by rehydration.

Table.1 Weekly averages of Temperature Humidity Index during the experiment

\begin{tabular}{|c|c|c|}
\hline \multirow{2}{*}{ Weeks } & \multicolumn{2}{|c|}{ Temperature Humidity Index } \\
\hline & $\mathbf{7 . 3 0}$ a.m. & $\mathbf{2 . 3 0 p . m .}$ \\
\hline $\mathbf{1}$ & 77.2 & 83.5 \\
\hline $\mathbf{2}$ & 77.2 & 82.6 \\
\hline $\mathbf{3}$ & 76.8 & 85.3 \\
\hline $\mathbf{4}$ & 75.8 & 84.3 \\
\hline $\mathbf{5}$ & 74.3 & 82.7 \\
\hline $\mathbf{6}$ & 72.2 & 81.2 \\
\hline Mean & $\mathbf{7 5 . 6}$ & $\mathbf{8 3 . 3}$ \\
\hline
\end{tabular}

Table.2 Average physiologicalresponsesof sheep under different watering frequencies during the experiment

\begin{tabular}{|c|c|c|c|c|c|c|}
\hline \multirow{2}{*}{$\begin{array}{l}\text { Physiological } \\
\text { responses }\end{array}$} & \multicolumn{3}{|c|}{7.30 a.m. } & \multicolumn{3}{|c|}{2.30 p.m. } \\
\hline & $\mathbf{T}_{1}$ & $\mathbf{T}_{2}$ & $\mathbf{T}_{\mathbf{3}}$ & $\mathbf{T}_{1}$ & $\mathbf{T}_{2}$ & $\mathbf{T}_{\mathbf{3}}$ \\
\hline $\begin{array}{l}\text { Pulse rate } \\
\text { (no./min.) }\end{array}$ & $76.31 \pm 1.37$ & $77.06 \pm 1.44$ & $77.08 \pm 1.69$ & $79.56 \pm 1.67$ & $80.00 \pm 0.84$ & $81.39 \pm 1.16$ \\
\hline $\begin{array}{c}\text { Respiration } \\
\text { rate } \\
\text { (no./min.) }\end{array}$ & $34.75 \pm 1.14$ & $35.19 \pm 0.98$ & $35.31 \pm 1.00$ & $71.53 \pm 1.31$ & $73.72 \pm 1.64$ & $74.22 \pm 1.35$ \\
\hline $\begin{array}{c}\text { Rectal } \\
\text { Temperature } \\
\left({ }^{\circ} \mathbf{F}\right)\end{array}$ & $101.60 \pm 0.08$ & $101.61 \pm 0.06$ & $101.63 \pm 0.05$ & $102.13^{b} \pm 0.06$ & $102.18^{b} \pm 0.08$ & $102.61^{\mathrm{a}} \pm 0.05$ \\
\hline
\end{tabular}

Means with dissimilar superscripts $(\mathrm{a}, \mathrm{b})$ in a row within 2.30 p.m.differed significantly $(\mathrm{P}<0.05)$

Table.3 Average physiological responses of sheep at 7.30 a.m. under rehydration phase of the experiment

\begin{tabular}{|c|c|c|c|c|}
\hline \multirow{2}{*}{$\begin{array}{l}\text { Physiological } \\
\text { responses }\end{array}$} & \multirow[t]{2}{*}{ Treatments } & \multirow{2}{*}{$\begin{array}{l}\text { Last week of different } \\
\text { watering frequencies }\end{array}$} & \multicolumn{2}{|c|}{ Rehydration } \\
\hline & & & $1^{\text {st }}$ day & $2^{\text {nd }}$ day \\
\hline \multirow{3}{*}{$\begin{array}{c}\text { Pulse rate } \\
\text { (no./min) }\end{array}$} & $\mathbf{T}_{1}$ & $71.33 \pm 4.28$ & $73.00 \pm 2.67$ & $71.67 \pm 3.44$ \\
\hline & $\mathbf{T}_{2}$ & $76.67 \pm 2.56$ & $77.67 \pm 1.82$ & $76.00 \pm 2.48$ \\
\hline & $\mathbf{T}_{3}$ & $74.33 \pm 2.50$ & $75.33 \pm 2.62$ & $73.00 \pm 1.77$ \\
\hline \multirow{3}{*}{$\begin{array}{l}\text { Respiration rate } \\
\text { (no./min) }\end{array}$} & $\mathbf{T}_{1}$ & $31.67 \pm 4.57$ & $33.33 \pm 3.89$ & $33.67 \pm 3.74$ \\
\hline & $\mathbf{T}_{2}$ & $31.50 \pm 2.78$ & $30.67 \pm 2.56$ & $28.67 \pm 2.62$ \\
\hline & $\mathbf{T}_{3}$ & $29.67 \pm 1.50$ & $30.00 \pm 1.55$ & $29.00 \pm 1.34$ \\
\hline \multirow{3}{*}{$\begin{array}{c}\text { Rectal } \\
\text { temperature } \\
\left.{ }^{\circ} \mathbf{F}\right)\end{array}$} & $\mathbf{T}_{1}$ & $101.37 \pm 0.26$ & $101.53 \pm 0.25$ & $101.48 \pm 0.24$ \\
\hline & $\mathbf{T}_{2}$ & $101.43 \pm 0.10$ & $101.52 \pm 0.08$ & $101.37 \pm 0.07$ \\
\hline & $\mathbf{T}_{3}$ & $101.45 \pm 0.12$ & $101.55 \pm 0.08$ & $101.35 \pm 0.08$ \\
\hline
\end{tabular}


Table.4 Average physiological responses of sheep at 2.30 p.m. under rehydration phase of the experiment

\begin{tabular}{|c|c|c|c|c|}
\hline \multirow{2}{*}{$\begin{array}{l}\text { Physiological } \\
\text { responses }\end{array}$} & \multirow[t]{2}{*}{ Treatments } & \multirow{2}{*}{$\begin{array}{l}\text { Last week of different } \\
\text { watering frequencies }\end{array}$} & \multicolumn{2}{|c|}{ Rehydration } \\
\hline & & & $1^{\text {st }}$ day & $2^{\text {nd }}$ day \\
\hline \multirow{3}{*}{$\begin{array}{l}\text { Pulse rate } \\
\text { (no./min) }\end{array}$} & $\mathbf{T}_{1}$ & $78.67 \pm 6.17$ & $78.33 \pm 5.62$ & $78.00 \pm 5.37$ \\
\hline & $\mathbf{T}_{2}$ & $80.67 \pm 1.52$ & $80.33 \pm 0.95$ & $78.67 \pm 1.33$ \\
\hline & $\mathbf{T}_{3}$ & $79.33 \pm 2.76$ & $79.00 \pm 3.04$ & $78.33 \pm 3.44$ \\
\hline \multirow{3}{*}{$\begin{array}{c}\text { Respiration rate } \\
\text { (no./min) }\end{array}$} & $\mathbf{T}_{1}$ & $64.33 \pm 1.67$ & $63.00 \pm 1.69$ & $65.00 \pm 1.98$ \\
\hline & $\mathbf{T}_{2}$ & $70.67 \pm 5.65$ & $68.33 \pm 4.83$ & $67.67 \pm 4.72$ \\
\hline & $\mathbf{T}_{3}$ & $64.33 \pm 3.03$ & $64.00 \pm 3.61$ & $62.00 \pm 3.06$ \\
\hline \multirow{3}{*}{$\begin{array}{c}\text { Rectal } \\
\text { Temperature }\left({ }^{\circ} \mathbf{F}\right)\end{array}$} & $\mathbf{T}_{1}$ & $101.95 \pm 0.14$ & $101.93 \pm 0.18$ & $101.98 \pm 0.22$ \\
\hline & $\mathbf{T}_{2}$ & $102.07 \pm 0.16$ & $102.05 \pm 0.20$ & $102.02 \pm 0.21$ \\
\hline & $\mathbf{T}_{3}$ & $102.42 \pm 0.13$ & $102.43 \pm 0.14$ & $102.23 \pm 0.17$ \\
\hline
\end{tabular}

Water restriction caused a rise in rectal temperature of Awassi sheep, but had no effect on either respiration or pulse (Wali and Ashir, 1990) is in accordance with the present study.Water deprivation resulted in a significant increase in rectal temperature (Abdelatif et al., 2010). Rectal temperature and respiration rate of goats increased from morning to afternoon (Kheir and Ahmed, 2008). Similarly, Alamer (2006) reported an increase in the $\mathrm{pm}$ values of rectal temperature following water deprivation in indigenous goat breeds (Hipsi, Aardi and Zumri) of Saudi Arabia. The rectal temperature of indigenous sheep recorded at $2.30 \mathrm{pm}$ significantly $(\mathrm{P}<0.05)$ elevated when animals were subjected to $40 \%$ water restriction as compared to 20 and $0 \%$ water restriction (Neelam et al., 2016) supported the present findings.

The study can be concluded that the rectal temperature of experimental animals recorded at 2.30 p.m. was significantly $(\mathrm{P}<0.05)$ influenced by watering frequencies. Whereas, all other physiological responses (respiration rate and pulse rate at 7.30 a.m. and 2.30 p.m. and rectal temperature at 7.30 a.m.) were at par among different watering frequencies. The physiological parameters of experimental animals were non-significantly influenced by rehydration.

\section{References}

Abdelatif, A. M., Elsayed, S. A. and Hassan, Y. M. 2010. Effect of state of hydration on body weight, blood constituents and urine excretion in Nubian Goats (Capra hircus). World J. Agric. Sci., 6(2): 178188.

Alamer, M. 2006. Physiological responses of Saudi Arabia indigenous goat to water deprivation. J. Small Ruminant Research, 63: 100-109.

Alamer, M. 2009. Effect of water restriction on lactation performance of Aardi goats under heat stress conditions. Small Rum. Res., 84: 76-81.

Alamer, M. 2010. Effect of water restriction on thermoregulation and some biochemical constituents in lactating Aardi goats during got weather conditions. Journal of Basic and Applied Scientific Research, 11: 189205.

Casamassima, D., Vizzarri, F., Nardoia, M. and Palazzo, M. 2016. The effect of water-restriction on various physiological variables in intensively reared Lacaune ewes. Veterinarni Medicina, 61(11): 623-634.

ICAR, 2013. Nutrient requirements of Livestock and Poultry. Indian Council of Agricultural Research, New Delhi, 
India.

Kheir, I. M. and Ahmed, M. M. M. 2008. Effects of water and feed restriction on some physiological and haematological parameters and blood constituents of Sudanese desert goats fed high and low quality forages under semi-arid conditions. Indian J. Anim. Res., 42(1): 39-43.

National Research Council, 2007. Nutrient requirements of small ruminants: sheep, goats, cervids, and new world camelids. Washington, D.C., p-384.

Neelam, G., Wadhwani, K. N., Islam, M. M. and Modi, R. J. 2016. Physiological responses of indigenous sheep under water restriction.Journal of Animal Research, 6(2): 331-333.

Saini, B. S., Kataria, N., Kataria, A. K. and Sankhala, L. N. 2013. Dehydration stress associates variation in rectal temperature, pulse and respiration rate of Marwari sheep. Journal of Stress Physiology and Biochemistry, 9(2): 1520.

Wali, S. A. and Ashir, A. M. 1990. Physiological responses of Awassi sheep to water and feed restriction. Indian J. Animal Sci., 60(6): 690-692.

\section{How to cite this article:}

Sahana, M., R. J. Modi, M. M. Trivedi, M. M. Islam and Wadhwani, K. N. 2020. Impact of Watering Frequencies and Rehydration on Physiological Responses of Indigenous Sheep. Int.J.Curr.Microbiol.App.Sci. 9(08): 557-561. doi: https://doi.org/10.20546/ijcmas.2020.908.063 